Most government laboratories in the United States rely on the unstinting support of their local political representatives, without which they are unlikely to win battles with other laboratories for programmatic funding. It is almost inconceivable, for example, that the Department of Energy would try to get money to restart HFBR if D'Amato and Forbes continue to oppose this.

Nancy Connell, a spokesperson for RPI, says that it decided not to bid on Saturday, and informed Westinghouse on that day. "We had to reach a determination as to whether winning the contract would positively impact our mission as a university," she says. "We decided that it would not". She denies that the statements from D'Amato and Forbes played a part in the decision.

Peña met D'Amato and Forbes on Friday. He told them that the DoE would not accede to their demand that the reactor be closed immediately, but instead proceed with its plan to consult with scientists and the Long Island community before making a decision early next year (see Nature 388,$503 ; 1997)$.

The statement from D'Amato and Forbes infuriated staff at Brookhaven, several hundred of whom protested outside Forbes' local headquarters last week. In July, Forbes told staff that he hoped research would resume at the HFBR. There is "a sense of outrage and betrayal" at the laboratory over Forbes' new position, one employee said. Colin Macilwain

\title{
US DoE laboratories need 'compelling' missions
}

[WASHINGTON] Federico Peña, the US Energy Secretary, has pledged to accelerate reforms in the Department of Energy's management of its national laboratories, admitting that he has been tardy in implementing recommendations from two advisory groups.

Addressing his Secretary of Energy Advisory Board (SEAB) last week for the first time since his appointment earlier this year, Peña announced he had ordered further reviews that could lead to a rationalizing of DoE's headquarters and field management structure. Peña also said he will develop a 15-20 year plan for the laboratories' facilities which are used by the wider scientific community, such as synchrotrons, neutron sources and other 'big science' facilities.

Earlier this year the DoE was urged both by its Laboratory Operations Board, a panel of external advisers and senior department officials, and an outside assessment prepared by the Institute for Defense Analyses - to streamline its management of laboratories and establish clearer lines of authority between these and the DoE programme offices which fund them.

Peña told SEAB that he "agreed ... that there are too many people in the DoE management system. that there are unclear lines of authority and diffused responsibility" and that this had created "inefficiencies that hurt the performance of the laboratories." He has instructed DoE's R\&D Council, a group of senior DoE managers, to introduce schemes to reduce the amount of paperwork demanded of DoE scientists.

He also asked the council to draft within 90 days a plan to strengthen the technical competence of DoE's R\&D programme management. If this approach proved not to be feasible, an alternative might be for the department to delegate greater responsibility for management to the laboratories themselves.

DoE programme offices have also been asked to prepare plans spelling out a compelling mission for their programme, and how this would be achieved, including defining the roles of laboratories involved. Peña held up as an example the agency's nuclear weapons laboratories "well-developed" stockpile stewardship plan, which outlines a 10-year experimental programme for ensuring the safety and reliability of nuclear weapons without testing.

DavidKramer 